\title{
Variable penetration rate testing for shear strength of peat - a review
}

\section{Akeem Gbenga Amuda, Alsidqi Hasan, Fauzan Sahdi \& Siti Noor Linda Taib}

To cite this article: Akeem Gbenga Amuda, Alsidqi Hasan, Fauzan Sahdi \& Siti Noor Linda Taib (2018): Variable penetration rate testing for shear strength of peat - a review, International Journal of Geotechnical Engineering, DOI: 10.1080/19386362.2018.1464816

To link to this article: https://doi.org/10.1080/19386362.2018.1464816

曲 Published online: 08 May 2018.

Submit your article to this journal $\sqsubset$

Q View related articles $\llbracket$

View Crossmark data \lceil 


\title{
Variable penetration rate testing for shear strength of peat - a review
}

\author{
Akeem Gbenga Amuda ${ }^{\text {(D) }}$, Alsidqi Hasan ${ }^{\text {(D) }}$, Fauzan Sahdib and Siti Noor Linda Taiba

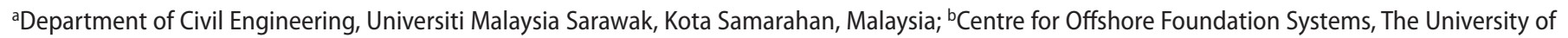 \\ Western Australia, Perth, Western Australia, Australia
}

\begin{abstract}
This paper presents a review of the advances in the variable penetration rate testing methods on inorganic soils and its potentials to investigate the appropriate penetration rate and resistance factors for penetrometer testing of peat. A partially drained condition, which often leads to misinterpretation of test results, has been observed in peat penetration testing when the standard rate of $20 \mathrm{~mm} / \mathrm{s}$ is used. Although the impact of rate-effects on penetration resistance measured with CPTu, T-bar and ball penetrometer have been investigated extensively in various intermediate soils, research is limited on how penetration rate controls drainage conditions and affects consolidation behaviour in peat. This review synthesises research developments in using variable penetration rate tests. The objective is to evaluate the transition of drainage conditions and consolidation behaviour of inorganic soils while focusing on its adaptability for peat. The review provides guidance on the investigation of the penetration rate testing in peat.
\end{abstract}

ARTICLE HISTORY

Received 9 February 2018

Accepted 10 April 2018

\section{KEYWORDS}

Peat; penetrometer; variable penetration rate; resistance factor; drainage condition; calibration chamber

\section{Introduction}

In some part of the world, urbanisation necessitates expansion to peatlands due to insufficient good land space. In Malaysia, commercial corridors, regional highways, housing estates and other developments are to be extended to peatlands to meet up with the aspiration of being a developed country by the year 2020 (Al-Ani, Oh, and Chai 2013). Peat is known to be a problematic material because of its high organic content and poor mechanical performance. Peat in Malaysia and other countries like Australia, Ireland and the Netherlands is susceptible to problems of instability, excessive settlement, landslides, embarkment and slope failure among others. These geotechnical challenges are majorly attributed to uncertainties in estimating the shear strength correctly, although the shear strength of peat is low on account of high permeability and large deformation characteristics. It is more conservative to assume drainage state of peat at failure to be in an undrained condition for design purposes (Boylan, Jennings, and Long 2008; Boylan and Long 2013; O’Kelly 2014). Evidence has shown that most of the embankments failures on peat, peat dams and slopes occur with undrained response (Den Haan and Feddema 2012; Long and Jennings 2006; McInerney, O'Kelly, and Johnston 2006; Van Baars 2005)

Triaxial and direct shear box directly measure shear strength parameters in the laboratory while vane shear test (VST) is known as the most common in situ tool for directly measuring the undrained strength of peat. However, their testing apparatus and procedures do not conform with the nature of peat. Therefore, any shear strength parameters obtained from these tests are susceptible to error (Boylan and Long 2007; Farrell
2012; Landva 1986; O’Kelly 2014; Zhang and O’Kelly 2014). Undisturbed sampling of peat for laboratory testing is difficult because of the unavoidably large disturbance when using conventional sampling methods. The fibrous nature of peat and high compressibility contribute to the uncertainties in interpreting the laboratory data of peat. Similarly, the VST has been shown to be problematic, since peat fibres may wrap around the rotating vane and water drains behind the vane, thereby inducing artificially high undrained strength measurements (Landva 1980).

In recent times, $\mathrm{CPTu}$, T-bar and ball penetrometers have emerged as better alternative tools for estimating the undrained shear strength of peat through penetration resistance measurement. The penetration test is carried out on the field by advancing the penetrometer into the soil, at a specified rate. However, penetration testing of peat with the standard rate of $20 \mathrm{~mm} / \mathrm{s}$ specified by ASTM has been observed to be in a partially drained condition (Boylan, Long, and Mathijssen 2011; Lunne, Robertson, and Powell 1997). Penetration testing at the standard rate of $20 \mathrm{~mm} / \mathrm{s}$ is expected to occur under a drained condition in sandy soil and fully undrained condition in clay for succinct interpretation of penetration test data as either drained or undrained shear strength. The permeability properties of peat suggest that the ASTM standard rate may not be able to produce an undrained condition in peat. Because the pore water pressure dissipates gradually, partial consolidation occurs and penetration resistance will increase above that of the actual undrained condition (Mahmoodzadeh and Randolph 2014). Any analysis and design computed based on such condition will not effectively represent the potential geotechnical failure mechanism of peat under the undrained condition. 